\title{
KOMUNIKASI SUAMI DAN ISTRI DALAM HADIS NABI
}

\author{
Nawawi Marhaban \\ Dosen Fakultas Ushuluddin Adab dan Dakwah \\ Institut Agama Islam Negeri Langsa
}

\begin{abstract}
Abstrak
Keluarga merupakan kelompok sosial yang terkecil dalam masyarakat. Keluarga dapat dibentuk dengan terlebih dahulu melakukan pernikahan. Oleh karena itu pernikahan dilakukan agar mewujudkan keharmonisan keluarga. Keharmonisan keluarga akan menjadi cita-cita bagi setiap pasangan suami istri. Untuk mewujudkannya maka diperlukan pemahaman dan pengertian dari masing-masing pasangannya. Penelitian yang dilakukan oleh Chuang (Chuang, 2005: 272-291.) menyebutkan bahwa kesejahteraan dan keharmonisan keluarga dapat dilihat dari harapan peran dan saling melengkapi antar anggota keluarga. Walaupun keluarga harmonis menjadi yang didambakan namun pada kenyataannya dalam berkeluarga tidak selalu berjalan dengan baik. Persioalan komunikasi menjadi salah satu alasan utama ketidak harmonisan dalam rumah tangga,data yang diperoleh Depkumham (2011) menunjukan adanya peningkatan KDRT dari tahun 2001 sampai dengan 2007. Kemudian perceraian yang terjadi pada tahun 2010 merupakan yang tertinggi dalam kurun 5 tahun terakhir, Hal tersebut disebabkan karena konflik komunikasi, ekonomi, dan kebutuhan psikologisPadahal salah satu fungsi komunikasi dalam hubungan keluarga adalah untuk mempererat hubungan dengan orang lain atau sebaliknya. Komunikasi sangat penting dalam hubungan keluarga, sebab tanpa komunikasi hubunganhubungan yang akrab tidak dapat terjalin. Pada saat ini, fenomena komunikasi memiliki relevan yang teramat kuat bagi berlangsung dan lestarinya sistem kehidupan rumah tangga seseorang.
\end{abstract}

Kata Kunci : Komunikasi, Suami-Istri, Hadist

\section{A. Komunikasi Suami Dan Istri Dalam Hadis Nabi}

Komunikasi antarpribadi adalah satu bentuk komunikasi yang menjadi dasar dalam usaha memahami kehidupan bersama. Hal tersebut dapat terlihat dalam sebuah hubungan antar pribadi suami dan istri. Keharmonisan sebuah rumah tangga sangat berkorelasi dengan kemampuan suami maupun istri dalam membangun sebuah komunikasi yang efektif. Segala permasalahan dan konflik dalam rumah tangga akan dapat terselesaikan dengan adanya komunikasi yang efektif antara suami dan istri.

Terlebih tuntunan ajaran Islam mengenai hal ini lebih dari cukup, Rasulullah sendiri banyak mengemukakan hadis-hadis yang berkaitan tentang komunikasi antara suami dan istri, bagaimana kewajiban suami kepada istri demikian juga sebaliknya kewajiban yang 
harus dilakukan oleh istri kepada suami, oleh karena demikian sangat penting rasanya membahas tentang hadis yang berkaitan dengan komunikasi suami dan istri.

Berkaitan dengan hadis tentang komunikasi suami istri, penulis mengangkat tentang hadis istri wajib meminta izin kepada suami terdapat beberapa poin yang disebutkan dalam redaksi hadis yaitu hadis Bukhari nomor 4796(Lidwa Pustaka i-Software: Kitab Sembilan Imam)Sedangkan hadis lainnya sebagai penguat penulis temukan di beberapa tempat, dengan beberapa perbedaan lafaz. Penulis menemukan banyak hadis lainnya yang membahas tentang tema ini dengan redaksi lafaz yang sedikit berbeda.

Diantaranya terdapat dalam Kitab Shahih Muslem nomor 1704, Hadis Ahmad No 9357, Abu Daud juga memasukkan dalam kitabnya hadis nomor 2102, Dari keseluruhan hadis tersebut, umumnya mempunyai redaksi lafaz yang hampir sama. Perbedaannya terletak di perinciannya saja.

Adapun rincian matan hadisnya adalah sebagai berikut:

a. Matan Hadis Bukhari No 4796 (Lidwa Pustaka i-Software: Kitab Sembilan Imam)

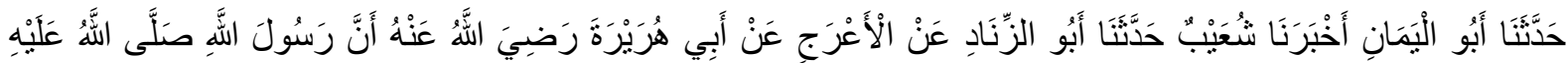

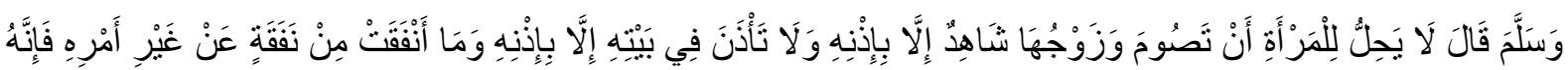

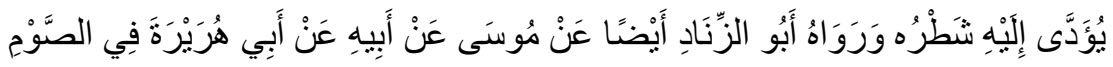

Artinya: "Telah menceritakan kepada kami Abul Yaman Telah mengabarkan kepada kami Syu'aib Telah menceritakan kepada kami Abu Zinad dari Al A'raj dari Abu Hurairah radliallahu 'anhu, bahwa Rasulullah shallallahu 'alaihi wasallam bersabda: "Tidak halal bagi seorang wanita untuk berpuasa sementara sementara suaminya ada di rumah, kecuai dengan seizinnya. Dan tidak boleh mengizinkan seseorang masuk ke dalam rumahnya kecuali dengan seizinnya. Dan sesuatu yang ia infakkan tanpa seizinnya, maka setengahnya harus dikembalikan pada suaminya."

Hadits ini juga diriwayatkan oleh Az Zinad dari Musa dari bapaknya dari Abu Hurairah dalam bab shaum.

$$
\text { وَرَوَاهُ أَبُو الزَّنَادِ أَيْضًا عَنْ مُوسنى عَنْ أَبِيهِ عَنْ أَبِي هُرَيْرَةَ فِي الصَّوِْْ }
$$

Kalimat ini menginformasikan bahwa hadis ini diriwayatkan pula oleh Abu al-Zinad melalui jalur lainnya yaitu dari Musa, dari ayahnya yang masih dari Abi Hurairah. Itulah komentar al-Bukhari. Hadis ini sangat popular di kalangan ahli hadis, bahkan tiga imam dari penyusun al-Kutub al-Sittah meriwayatkannya dengan berbagai jalur atau mata rantai hingga sampai pada mereka. Adapun redaksinya ada yang sama ada pula yang berbeda. 


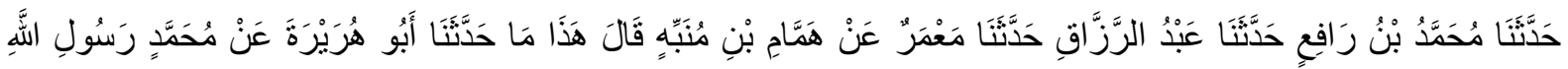

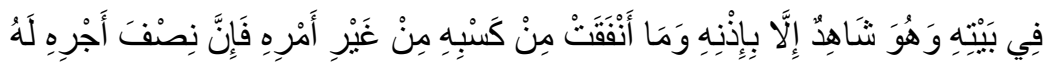

Artinya: "Telah menceritakan kepada kami Muhammad bin Rafi' telah menceritakan kepada kami Abdurrazaq telah menceritakan kepada kami Ma'mar dari Hammam bin Munabbih ia berkata; ini adalah hadits yang telah diceritakan oleh Abu Hurairah kepada kami, dari Muhammad Rasulullah shallallahu 'alaihi wasallam. Ia pun menyebutkan beberapa hadits, di antaranya adalah- Dan Rasulullah shallallahu 'alaihi wasallam bersabda: "Seorang wanita janganlah berpuasa (sunnah) ketika suaminya ada, kecuali dengan seizinnya. Dan jangan pula ia membolehkan orang lain masuk ke rumahnya melainkan dengan izin suaminya. Dan sesuatu yang disedekahkan oleh sang isteri dari usaha suaminya tanpa perintah suami, maka setengah dari pahala sedekah itu bagi suaminya."

c. Matan Hadis Ahmad No 9357(Lidwa Pustaka i-Software: Kitab Sembilan Imam)

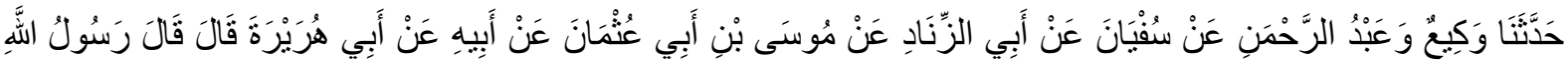

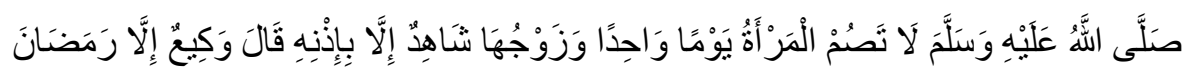

Artinya: "Telah menceritakan kepada kami Waki' dan Abdurrahman dari Sufyan dari Abu Az Zinad dari Musa bin Abi Utsman dari bapaknya dari Abu Hurairah berkata; Rasulullah shallallahu 'alaihi wasallam bersabda: "Janganlah seorang istri berpuasa sehari penuh ketika ada suaminya kecuali dengan izinnya." Waki' menyebutkan, "Kecuali pada bulan Ramadhan."

d. Matan Hadis Abu Daud No 2102(Lidwa Pustaka i-Software: Kitab Sembilan Imam)

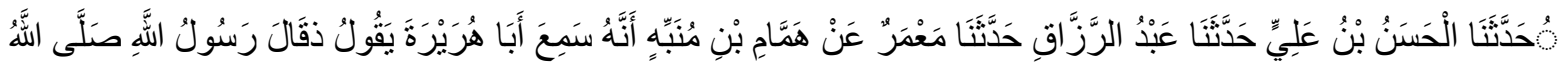

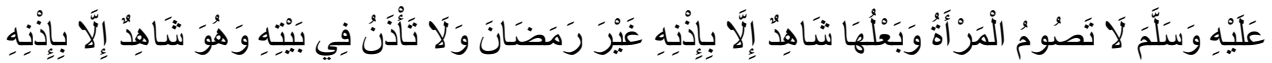

Artinya: "Telah menceritakan kepada kami Al Hasan bin Ali, telah menceritakan kepada kami Abdurrazzaq, telah menceritakan kepada kami Ma'mar, dari Hammam bin Munabbih, bahwa ia mendengar Abu Hurairah berkata; Rasulullah shallallahu 'alaihi wasallam bersabda: "Seorang wanita tidak boleh berpuasa sementara suaminya berada di sisinya kecuali dengan seizinnya selain puasa pada Bulan Ramadhan dan tidak boleh ia mengizinkan seseorang di dalam rumahnya sementara suaminya berada di sisinya kecuali dengan seizinnya."

Adapun asbabul wurud hadis utama di atas sebagai berikut: Diriwayatkan oleh lmam Ahmad, Abu Daud dan Imam al-Hakim dari Abi Sa'id, dia berkata "Pada suatu hari ada seorang wanita datang menghadap Rasulullah SAW, kami (suaminya) waktu itu kebetulan sedang berada di sisi Nabi”. Wanita ini berkata; Ya Rasulullah SAW, sesungguhnya suami 
saya, yaitu Shafwan bin al-Mua'aththal suka memukuli saya ketika saya shalat dan menyuruh saya untuk membatalkan puasa ketika akan berpuasa (puasa sunnah), dia juga sering terlambat shalat subuhnya sampai terbit matahari.

Namun, ternyata ketika hal itu diadukan suaminya yang bernama Shafwan tersebut ada di samping Nabi, beliau bertanya kepada Shafwan, Ya Rasulullah sebenarnya saya memukuli istriku ketika dia shalat dia terlalu lama, ia suka membaca dua surat Alquran maka Nabi berkata; sebenarnya seandainya ia ketika shalathanya membaca satu surat saja sudah cukup. Kemudian mengapa saya (Shafwan) menyuruhnya berbuka puasa? Sebab ia suka bepergian dan suka berpuasa (sunnah) sementara saya masih muda dan saya tidak bisa atau kuat menahan gejolak nafsu, maka Nabi berkata:

"Hendaknya seorang istri tidak berpuasa sunnah, dan dalam redaksi riwayat lmam Ahmad mengatakan: "Janganlah sekali-kali istri kalian berpuasa kecuali atas izin suaminya"

Lalu mengapa saya (Shafwan) tidak shalat pada waktu subuh kecuali jika hampir terbit matahari, karena saya tidak bisa bangun pagi kecuali jika matahri sudah terbit, maka Nabi berkata: Apabila kamu bangun maka shalatlah. ( Ibn Hamzah al-Dimasyqi,1379:281)

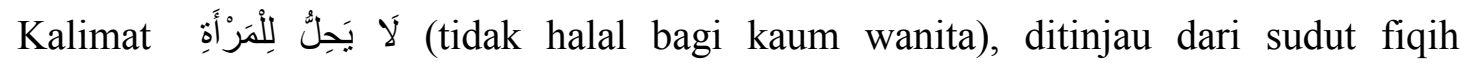
menunjukkan keharaman, karena setiap yang tidak halal adalah haram. Memang ada ulama yang berpendapat bahwa hukumnya adalah makruh, karena kalimat tidak halal tidak semua

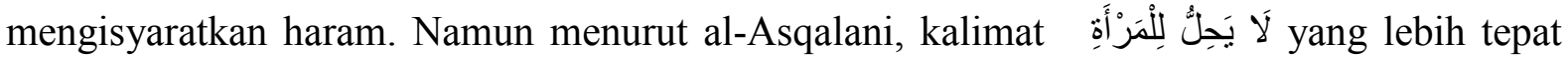
diartikan hukumnya haram bagi kaum wanita, sebagai mana menurut mayoritas ulama. ( Ibnu

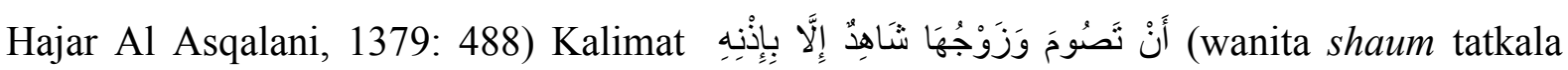
suaminya hadir, kecuali dengan seizinnya. Menurut riwayat muslim (206-261H)

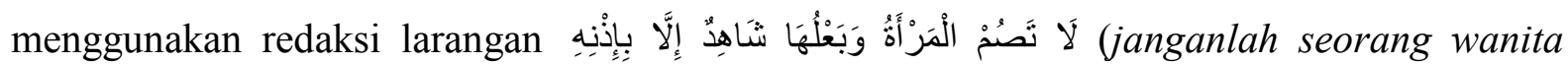
shaum ketika suaminya ada kecuali dengan izinnya).(Muslim Ibn Hajjaj al-Naisaburi, 1989:1704) Yang diharamkan di sini adalah shaumtathawwu' (puasa sunat)bukan shaum wajib, sebagaimana terungkap dalam riwayat al-Tirmidzi (209-279H) dan Ibn Majah (207-

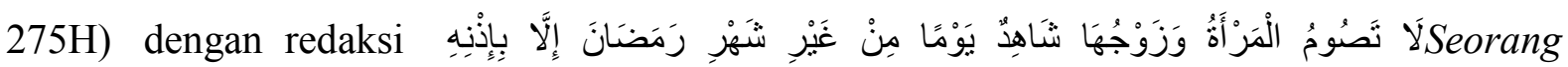
perempuan tidak dibenarkan shaum sehari pun padahal suaminya hadir, selain shaum ramadlan kecuali dengan izinnya.

(At-Tirmizi, 1998:713)

An-Nawawi (631-676H), menegaskan bahwa larangan ini mengisyaratkan haramnya wanita shaum sunat ketika suaminya hadir kecuali atas izinnya, karena shaum sunat itu waktunya tidak sempit boleh dilaksanakan di hari lain. Adapun salah satu sebabnya 
diharamkan adalah seorang suami mempunyai hak untuk bersenang-senang dengan istrinya kapanpun.

Memenuhi keinginan suami untuk menenyangkannya adalah menjadi kewajiban seorang istri. Oleh karena itu tidak boleh dikalahkan dengan ibadah yang disunnahkan. Ada yang berpendapat bahwa shaum sunat tanpa izin suami itu semestinya dibolehkan saja, tapi tatkala suaminya menginginkan sesautu dari istri yang menimbulkan batalnya shaum, maka istrinya mesti membatalkan shaumnya, umpamanya menginginkan makan berasama atau sebangsanya.

An-Nawawi menjawab pendapat tersebut dengan menegaskan bahwa shaumnya sang istri bisa mengganggu kebebasan suami untuk memenuhi keinginanya, maka semestinya minta persetujuan terlebih dahulu. ( Abu Zakariya Muhyeddin,1392:474)

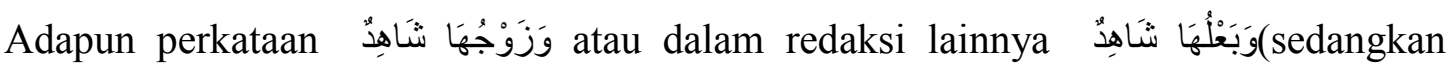
suaminya menyaksikan atau hadir) mengisyaratkan bahwa istri dilarang berpuasa (shaum) sunat tanpa persetujuan suaminya itu ketika suaminya berada di rumah atau sedang berbarengan dengannya. Jika suaminya itu sedang bepergian, sedangkan istrinya tidak ikut dan berada di rumah, maka istrinya boleh saja berpuasa tanpa minta persetujuan terlebih dahulu.

Namun menurut al-Asqalani, jika seorang istri sedang shaum padahal suaminya tidak di rumah, tiba-tiba di siang hari suminya datang dan menghendaki sesuatu yang membatalkan shaum, maka wajiblah istrinya itu membatalkan shaumnya. Larangan ini juga memberi isyarat bahwa di antara kebaikan istri pada suami adalah tidak melakukan ibadah yang hukumnya sunat yang menganggu keharmonisan rumah tangga.

Menjaga keharmonisan suami istri hukumnya wajib, maka jangan sampai terganggu oleh ibadah yang hukumnya sunat. Dalam riwayat Ibn Abi Syaibah diterangkan ada seorang waniya yang menghadap Rasul menanyakan tentang hak suami yang mesti dipenuhi istrinya, maka Rasul SAW bersabda: "Tidak dibenarkan seorang istri berpuasa tanpa persetujuan suaminya kecuali yang difardzukan. Jika istrinya tetap melakukan shaum maka termasuk dosa dan tidak akan diterima shaumnya. (Ibnu Syaibah,T.Th: 507)

Kalimat إِلَّ بِإِنْنِـ juga mengandung arti syarat dikabulnya ibadah sunat yang dilakukan seorang istri adalah persetujuan suami. Persetujuan tersebut baik dalam bentuk kalimat langsung ataupun tidak langsung. Namun bukan berarti istri dilarang melakukan semua ibadah sunat tanpa izin suami. Sepanjang ibadah sunat yang dilakukannya itu tidak menganggu keharmonisan suami istri maka dapat dijalankannya. (Ibnu Hajar, 
1379:488) Larangan ibadah shaum sunat bagi istri tanpa persetujuan suami, juga memberi isyarat adanya kemestian mendahulukan kewajiban di banding yang hukumnya sunat. Tegasnya larangan ini tidak mencakup shalat sunat yang hanya membutuhkan waktu singkat. ( Al-Hafidh Muhammad, T.Th:326)

Namun jika ibadah yang hukumnya sunat itu dapat mengganggu atau menghalangi kewajiban memelihara kebahagiaan suami istri, maka sepantasnya dihindari. Dalam riwayat Ahmad (164-24 H) bahkan ditegaskan seorang istri dilarang shaum sunat tanpa iizin suaminya walau hanya satu hari. Perhatikan redaksinya:

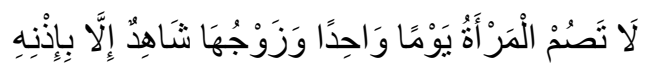

Janganlah seorang perempuan shaum walau hanya satu hari, padahal suaminya ada kecuali dengan izinnya. Hr. Ahmad. (Abu Abdillah, 2001:9357)

Kalau ibadah tathawwu' itu mesti mendapat izin dari suami, maka secara tersirat seorang suami boleh saja membatasi istrinya dalam melakukan ibadah tathawwu' yang diperkirakan mengganggu hak dan kewajiban. Secara tersurat hadits ini melarang istri beribadah tathawwu' tanpa izin suaminya.

Dalam hadis di atas memang tidak dibahas tentang bagaimana suami melakukan ibadah tathawwu' tanpa izin istri, apakah dibolehkan sepanjang tidak mengganggu keharmonisan? Tidak ditemukan hadis yang secara tersurat melarangnya.

Namun hal ini tentu berkaitan dengan kewajiban suami menjaga perasaan sang istri. Itulah mungkin salah satu hikmahnya, Rasul minta izin siti Aisyah untuk bertahajjud. Beliau bersabda pada Aisyah:

"Wahai Aisyah! sudikah dikau membiarkan diriku beribadah pada Tuhanku semalam ini? Aisyah menjawab: demi Allah seungguhnya diriku sangat mencintai dekat denganmu dan aku sangat mencintai apa yang engkau senangi yang menyenangkanmu"

Kemudian Rasul SAW bersuci dan melaksanakan qiam al-Lail. Hr. Ibn Hibban. (Muhammad Ibnu Hibban,1993:238)

Hadis ini mengisyaratkan bertapa Rasul SAW memperlakukan istrinya dengan akhlaq yang mulia. Beliau meminta izin Aisyah terlebih dahulu tatkala akan melakukan ibadah di waktu malam.

Budi pekerti beliau merupakan teladan bagi setiap suami. Dengan demikian tidak hanya sang istri minta izin suami untuk melakukan ibadah tathawwu', suami pun diperlukannya untuk menjaga keharmonisan keluarga. Ibadah ritual yang hukumnya tathawwu atau sunat secara fiqhiyah memang tidak boleh mengganggu kewajiban yang sifatnya sosial. Itulah mungkin salah satu hikmahnya mengapa Rasul SAW membatasi umat 
yang ingin beribadah melebihi beliau. Puasa tidak boleh setiap hari, shalat malam pun tidak boleh semalam suntuk. Abdullah bin Amr bin Ash menerangkan bahwa tatkala beliau bertekad untuk memperbanyak ibadah, Rasul SAW bersabda:

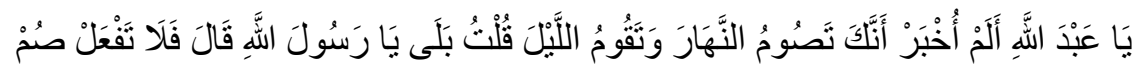

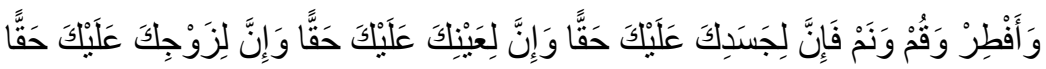

Artinya: "Wahai Abdullah! Kabarnya engkau selalu shaum di siang hari, dan bangun malam. (kata Ibn Amr) betul wahai Rasul! Beliau bersabda: jangan engkau lakukan seperti itu! Shaumlah dan berbuka lah! Bangunlah malam dan tidurlah sebagiannya. Sesungguhnya jasadmu punya hak untuk kemu penuhi. Matamu juga punya hak untuk kamu penuhi. Istrimu juga punya hak untuk kamu penuhi kebutuhannya" Hr. al-Bukhari (194-256H). Dalam buku Shahih al-Bukharioleh (Muhammad Ibnu Ismail,1432H:4800)

Dalam riwayat Ahmad (164-241) ditegaskan:

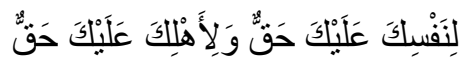

Dirimu punya hak yang mesti kamu penuhi, keluargamu juga punya hak yang mesti kemu penuhi. Hr. Ahmad. ( Abu Abdillah, 2001:6583)

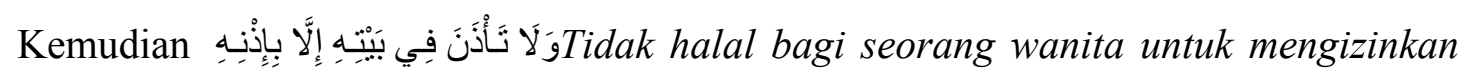
orang lain masuk ke rumahnya, tanpa seizin suaminya. Kalimat ini tidak terpisahkan dengan kalimat sebelumnya yang menggunakan kata sambung secara mutlak. Dengan demikian نَأْنَنَ pada hadis ini bermakna tidak halal bagi seorang perempuan memberi izin di rumahnya

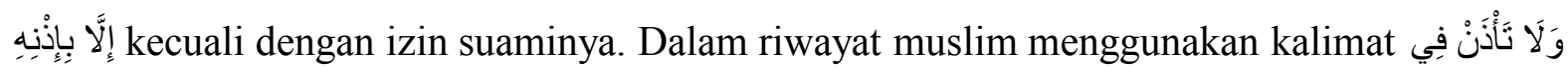
Tidak halal bagi seorang wanita padahal suaminya hadir, untuk mengizinkan orang lain masuk ke rumahnya, tanpa iznin suaminya.

Namun kalimat وَهُوَ شَكَاهدِ bukan berarti membolehkan memberi izin ketika suaminya tidak ada, tapi sebagai penegasan atau menguatkan kalimat sebelumnya. Berfungsi pula sebagai yang mengandung arti ketika ada suaminya di rumah mesti minta izin terlebih dahulu, untuk mempersilakan orang lain masuk rumah; apalagi tatkala suaminya tidak ada di rumah. Tegaslah seorang istri berkewajiban minta izin suami tatkala hendak mempersilakan orang lain masuk ke rumah, baik suaminya ada di rumah ataukah sedang tiada. Salah satu tanggung jawab istri terhadap suami adalah menjaga kehormatan diri, kehormatan suami dan juga kepemimpinan rumah tangga tatkala suaminya tiada di rumah.

Dalam sebuah hadis yang diriwayatkan oleh Abi Hurairah sebagai berikut:

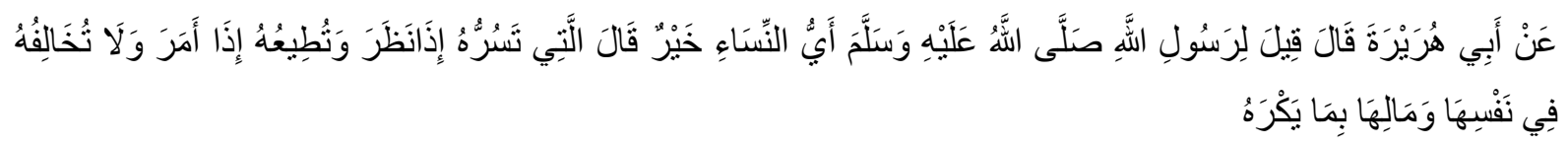

Artinya: Dari Abi Hurairah, berkata: Rasul SAW ditanya: Wanita yang bagaimanakah yang terbaik? Beliau menjawab yang menyenangkan suami tatkala melihatnya, taat tatkala suami 
memerintah, tidak menyalahi suaminya dalam mengurus diri dan harta, hingga melakukan yang tidak disenangi. Hr. al-Nasa iy. ( Abu Abdurrahman,1989:27) Redaksi lainnya berbunyi

Berdasar penjelasan hadis di atas, jelaslah bahwa seorang istri bertanggung jawab untuk menjaga kemaslahatan rumahtangganya terutama tatkala suami tidak ada di tempat. Istri merupakan pemimpin rumah tangga mewakili suami yang sedang tidak di tempat. Di samping itu kalimat tidak menyalahi suaminya dalam mengurus diri dan harta menunjukkan bahwa pada prisipnya seorang istri tidak diperkenankan untuk melakukan hal-hal yang tidak disenangi suaminya, baik dalam urusan sikap diri maupun urusan pengelolaan harta.

Dikaitkan dengan pangkal hadis yang dibahas yang melarang puasa sunat tanpa izin suami, jelas berkaitan dengan urusan ibadah ritual, maka potongan hadis ini berkaitan dengan ibadah sosial yang ada hubungannya dengan sesama manusia. Kedua macam ibadah tersebut tentu saja sangat bernilai di sisi Allah maupun sisi manusia. Namun ternyata berdasar hadis yang dikaji di sini, baik ritual maupun sosial yang dilakukan seorang istri, mesti tetap atas izin suami, jelaslah jangan sampai mengganggu keharmonisan berkeluarga. Istri yang mengutamakan kepentingan keluarga khususnya keharmonisan dengan suaminya mendapat jaminan untuk mendapatkan surga di hari akhirat kelak. Rasul SAW bersabda:

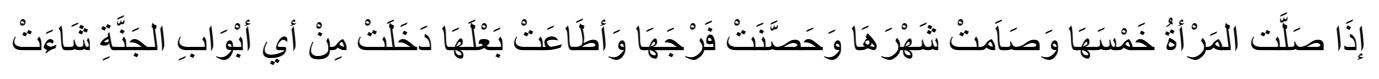

Artinya: "Jika perempuan itu menegakkan shalat lima waktu, shaum bulan ramadhan, menjaga kehormatannya, dan taat pada suaminya, maka akan masuk surga melalui pintu mana saja yang ia inginkan." Hr. Ibn Hibban (w. 354 H) dari Abi Hurairah.( Muhammad Ibnu Hibban, 1993:471)

Hadis ini berisi jaminan bagi isteri yang taat pada suami, bila ia menegakkan shalat, puasa, dan menjaga kehormatannya, akan masuk surga. Dengan demikian isteri yang setia pada suaminya, bukan hanya meraih derajat sebagai wanita terbaik di dunia, tapi juga menjadi ahli surga di akhirat kelak. Perintah suami yang mesti ditaati isteri, tentu saja yang tidak bertentangan dengan syari'at Islam. Jika perintahnya itu bertentangan dengan syari'at, maka yang mesti ditaati adalah Allah SWT dan Rasul-Nya. Siapa pun tidak dibenarkan menaati suatu perintah yang bertentangan dengan perintah Allah SWT. Timbul pertanyaan, bagaimana kalau seorang suami mengajak masuk perempuan lain ke rumahnya tanpa izin istri? Tentu saja jawabannya bukan dengan hadis ini, melainkan dalam ketentuan lainnya. Pada dasarnya baik suami maupun istri mesti berusaha saling menyenangkan dan menghindari hal-hal yang menimbulkan ketidaknyamanan pasangannya. Istri berkewajiban menjaga ketentraman dan kenyamanan suami. Suami pun berkewajiban menjaga ketentraman dan kenyamanan istrinya. 
Pada Prinsip komunikasi yang paling penting adalah kejelasan. Jadi apakah kita berhasil berkomunikasi atau tidak diukur dari satu yaitu apakah yang kita katakan didengar dan dipahami dengan jelas oleh lawan bicara kita. Komunikasi bukanlah hal yang mudah, apalagi kalau dikaitkan dengan konteks rumah tangga suami-istri. Salah satu ciri keluarga yang bermasalah adalah rusaknya komunikasi di antara suami dan istri.

Dari hadis di atas, menjelaskan tentang larangan seorang istri untuk berpuasa (sunnah) ketika sang suami bersama atau berada di sampingnya karena suatu hal yang akan kami jelaskan sebagai berikut.

Abu Daud menambahkan kalimat selain puasa Ramadhan. Dalam hadis tersebut juga terkandung dalil yang menunjukkan bahwa kesetiaan isteri untuk memenuhi hak suaminya lebih penting dari puasa sunnah. Tetapi puasa ramadhan wajib baginya meskipun suami tidak senang. Dikiaskan pada puasa Ramadhan itu, qadho puasa (sekiranya pernah meninggalkan puasa ramadhan itu). Seandainya sang istri tetap melakukan puasa sunnah tanpa sepengetahuan atau seizin suaminya. Maka dia telah melakukan perbutan haram.

Dalam hadis ini seorang isteri dilarang puasa sunnat tanpa izin dari suami. Larangan iniadalah larangan haram, sebagaimana yang dikatakan oleh Imam an-Nawawi rahimahullaah."Hal ini karena suami mempunyai hak untuk "bersenang-senang" dengan isterinya setiap hari. Hak suami ini sekaligus merupakan kewajiban seorang isteri untuk melayani suaminya setiap saat. Kewajiban tersebut tidak boleh diabaikan dengan alasan melaksanakan amalan sunnah atau amalan wajib yang dapat ditunda pelaksanaannya.”.

Apabila seorang isteri berkewajiban mematuhi suaminya dalam melampiaskan syahwatnya, maka lebih wajib baginya untuk mentaati suaminya dalam urusan yang lebih penting dari itu, yaitu yang berkaitan dengan pendidikan anak dan kebaikan keluarganya, serta hak-hak dan kewajiban lainnya. Al-Hafizh Ibnu Hajar rahimahullaah mengatakan, "Dalam hadis ini terdapat petunjuk bahwa hak suami lebih utama dari amalan sunnah, karena hak suami merupakan kewajiban bagi isteri. Melaksanakan kewajiban harus didahulukan daripada melaksanakan amalan sunnah”.Di samping itu juga, hadits di atas menjelaskan jika seseorang jangan terlalu lama dalam shalat sunnah. Tetapi hal ini tidak terlalu ditekankan.

Ketentraman, keharmonisan dan ketenangan keluarga merupakan tanggung jawab bersama suami dan istri. Suami maupun istri wajib memelihara kemaslahatan keluarga baik secara pribadi maupun bersama, maka tidak boleh terganggu oleh tindakan apapun walau yang sifatnya ibadah baik yang bersifat ritual maupun sosial. Tanggung jawab suami istri ada yang bersifat ritual seperti shaum, ada yang bersifat soasil hubungan dengan fihak yang lain, 
dan ada pula yang bersifat materi harta keluarga. Beribadah dengan ketiga hal itu mesti dilakukan sesuai proporsinya, tidak boleh mengganngu yang lainnya.

Apa yang dilakukan istri yang bersifat berdampak pada fihak suami, mesti dilakukan atas persetujuan suami. Demikian pula yang dilakukan suami bila berdampak pada hak istri, maka mesti dilakukan atas persetujuan istri. Infaq yang dikeluarkan istri pahalanya bukan hanya untuk dirinya, tapi juga untuk suaminya. Istri berpahala karena infaqnya; suami dapat pahala karena telah menyediakannya.

Harta dalam rumah tangga ada yang bersifat milik pribadi masing-masing suami istri; ada pula yang bersifat milik bersama. Yang menjadi milik pribadi masing-masing tentu saja punya kewenangan tanpa terhalang yang lain. Namun yang milik bersama mesti persetujuan bersama bila digunakan bukan untuk kepentingan bersama. Suami memiliki hak yang mesti dipenuhi oleh istrinya. Istri juga punya hak yang mesti dipenuhi oleh suaminya. Hak dan kewajiban masing-masing mesti dipenuhi sesuai ketentuan syari'ah.

Ibadah baik yang sifatnya ritual, sosial maupun harta mesti dilakukan sesuai aturan, tidak boleh berlebihan tidak pula berkekurangan dan mesti saling mendukung antara yang satu dengan yang lainnya sehingga terpeliahara kesimbangan. 


\section{B. Kesimpulan}

Seorang Istri harus selalu taat kepada suami apapun yang diperintahkan asalkan tidak bertentangan dengan aturan Allah dan RasulNya, Demikian juga suami harus menjaga istri dengan baik agar terciptanya komunikasi antara suami istri yang harmonis, Dalam perspektif ajaran islam populer dengan ungkapan keluarga sakinah. Keluarga sakinah adalah suatu ungkapan untuk menyebut sebuah keluarga yang penuh damai,tentram dan bahagia.Jadi keluarga sakinah adalah sebuah keluarga yang ideal dalam rumah tangga,yang secara fungsional dapat mengantar orang pada cita-cita dan tujuan untuk membangun keluarga. 


\section{DAFTAR PUTAKA}

Abdurrohman Al-Mubarokfuri, Al-Hafidh Muhammad. Tuhfah al-Ahwadzi. Beirut Darul Fikr, T.Th.

Ahmad An-Nasai, Abu Abdurrahman. Sunan al-Nasa `iy. Beirut: Maktab Matbu'ah Islamiyyah, 1989.

Ahmad Ibnu Hambal, Abu Abdillah. Musnad Ahmad. Beirut: Muassasah ar-Risalah, 2001.

Al Asqalani, Ibnu Hajar. Fath al-Bari. Beirut: Darul Ma’rifah, 1379.

Taqrib al-Tahdzib. Beirut: Darul Hadis, 1430.

At-Tirmizi, Jami' Qabir Sunan Al-Tirmidzi. Beirut: Darul Grarbi Al-Islami, 1998.Ibn Hajjaj, Muslim al-Naisaburi. Shahih Muslim. Beirut: Darul Ihya. T.Th

Ibn Hamzah al-Dimasyqi Al-Bayan Wa al-Ta'rif fi al-Hadits Wa Al-Atsar. Beirut: Darul Ma'rifah: 1379.

Ibnu Hibban, Muhammad. Shahih Ibn Hibban. Beirut: Muassasah ar-Risalah, 1993.

Ibnu Ismail, Muhammad. Shahih al-Bukhari. Beirut: Darul Tuqin Najah, 1432 H.

Ibnu Syaibah, Al-Mushannaf Ibnu Syaibah. Beirut Darul Ihya, T.Th.

Kalam Daud, Mohd. Implementasi Takhrij dan Kritik Sanad. Banda Aceh: Dinas Pendidikan NAD. 2004.

Khon, Abdul Majid. Ulumul Hadis. Jakarta: Amzah, 2008.

Lidwa Pustaka i-Software: Kitab Sembilan Imam.

Muhyeddin, Abu Zakariya. Syarah al-Nawawi ala Muslim. Beirut: Darul Ihya, 1392.

Narda, Bustami. Seni Berkomunikasi Dua Arah. Padang: Bebe Mustika, 2012.

Suryadi,et al. Metodologi Penelitian Hadis. Yogyakarta: Teras, 2009.

Yuslem, Nawir. Sembilan Kitab Induk Hadis. Jakarta: Hijri, 2011 